\title{
Quo Vadis, Serbia?
}

\section{A Multi-Vector Policy as a Way to Retain Political Agency}

\section{Elena G. Ponomareva}

\author{
Elena G. Ponomareva, PhD in Political Science, \\ MGIMO University of the RF Ministry of Foreign Affairs, Moscow, Russia \\ Comparative Politics Department \\ Professor \\ Scopus Author ID: 57006380000 \\ Researcher ID: M-6172-2014 \\ ORCID ID: 0000-0001-8370-8597 \\ E-mail: nastya304@mail.ru \\ Address: 76 Vernadsky Prospect, Moscow 119454, Russia \\ DOI: $10.31278 / 1810-6374-2020-18-1-158-179$
}

\begin{abstract}
Political agency (or political autonomy) is a major characteristic of international actors as it actually implies their capacity to conduct (relatively) independent foreign and domestic policies. Belgrade's chances of retaining its international status and building a "sovereign" democracy largely depend on the smart policy of balancing between two main centersthe EU-NATO and Russia. Notwithstanding the objectively predetermined nature of the European integration, the final choice is complicated for Serbia by the need to achieve a "compromise" on the Kosovo issue, and by its readiness to become a member of NATO. There is a natural counterbalance to Euro-Atlantic pressure-Russia, which has unique opportunities for building an international image of a great power while not claiming, in contrast to the EU, the role of an "empire by invitation." The Serbian situation is complicated by the fact that the historical dualism of the multi-vector policy has been upset by the emergence of a new player in the regionChina, which is using economic levers to successfully solve the strategic task of penetrating into European markets, thus consistently challenging
\end{abstract}


Russia's role as Serbia's main alternative to the West. The results of the analysis show that in the current situation, a multi-vector policy-smart balancing between three centers (EU-NATO, Russia, and China)-may open up opportunities for Serbia to exert political agency on the international stage in the near term.

Keywords: political agency, Serbia, the EU, Russia, China, NAT0, the Kosovo issue, multi-vector policy

or centuries, the Balkans has been and still is a turbulent, stra-
tegically vulnerable region in world politics. There are both
internal (deeply rooted historical) and external reasons for this. In the latter case, the persisting instability stems from the clash of interests among the leading players of our time. This specific feature of the region's development is yet another empirical confirmation of both the realistic tradition (Morgenthau, 1973; McKeogh, 2016) and the neo-realistic conception (Waltz, 1979) of the international system as "a set of elements which, interacting with each other, acquire a new quality that is absent in individual elements, and form a certain integral entity" (Fenenko, 2019, p. 65).

Today the focus of the world's attention of this part of Europe is on Serbia. This median and most significant state in the Western Balkans is central to the Euro-Atlantic integration strategy. However, the choice of the European development vector is complicated by a number of fundamental and intricate problems. First of all, it is the impossibility for a vast majority of Serbs to reconcile themselves with the territorial and metaphysical loss of the cradle of Serbian medieval statehoodKosovo and Metohija.

The second most important factor is the people's attitude to the NATO bombardments in 1999. A larger part of Serbian society remains firm: "We will not forget, we will not forgive." At the same time, incumbent President Aleksandar Vučić is inclined to find a compromise with the alliance, acting on the principle: "We are ready to forgive, but we will never forget." 
The lack of consensus on the issues that are so significant for modern Serbian society is aggravated by Brussels' adamant calls urging Belgrade to make an unequivocal choice between the European and Eurasian integration models. The perception of the latter as an exclusively Russian project has lost its relevance in recent years. Firstly, the strategic cooperation between Belgrade and Moscow is complemented by active inclusion of Serbia in the Eurasian Economic Union. Secondly, the Eurasian vector is increasingly acquiring Asian features: Beijing sees Serbia not only as the main "investment anchor" (Conley, Hillman and Melimo, 2019), but also as a center that can attract (bring together) the Balkan limitrophe states.

These processes are taking place in a situation where NATO is experiencing internal disbalance and even "brain death" (Briefing, 2019 , p. 18), and the EU is undergoing serious transformation. In this context, the verdict of European heavyweights voiced at the 2019 Western Balkans summit in Poznan was logical: the EU's enlargement must be postponed. The suspention of political and emotional expectations of a European future for Serbia was reaffirmed during Serbian President Aleksandar Vučićs talks with U.S. Secretary of State Michael Pompeo and European officials at the Economic Forum in Davos in January 2020: "No one from the EU or the U.S. was able to confirm that Serbia will be part of the EU" (Jamieson and Kumar, 2020). However, this circumstance does not cancel the extremely harsh EU requirements. To meet them, Serbia, according to Vučić, "would have to climb Mount Everest," which naturally cannot but affect the social and political climate in the country.

The analysis of all the factors stated above produced the following hypothesis: the need to break the deadlock of strategic vulnerability, preserve the historical and cultural identity and relative independence (while even world giants do not always enjoy full sovereignty due to global interdependence), and keep the important balance in the international agenda make Belgrade observe military neutrality and pursue a multi-vector foreign policy. The presence of several supporting (economic, political, military, cultural) factors will enable Serbia to maintain its status of a regional player and political agency on the international stage. 


\section{SERBIA IN THE CENTER OF THE EU/NATO-RUSSIA-CHINA TRIANGLE}

A short story titled "Dream Hunters" by Serbian writer Milorad Pavić shows an uneasy relationship between two characters-a man and a woman, whose names are unknown. The narration is conducted in the first person singular and ends with this: "Is it possible that I actually hated her? ... If the reader has not guessed it right yet, then here is the answer to the riddle. My name is the Balkans. And her name is Europe" (Pavić, 2003, p. 366).

Indeed, the history and the present state of relations between the Balkan and European countries are full of contradictions. It will not be an exaggeration to say that Serbs have had the most difficult relationship, at times on the brink of hatred, with Europe. Twice in the 20th century (during World War I and World War II) Serbia found itself in European trenches against the Second and Third Reichs and emerged from these battles in the ranks of victors. The geopolitical outcome of the bloody battles was Serbia's transformation into the core of the Balkan "empire"-royal (1918-1941) and socialist (1945-1991) Yugoslavia. The consequences of the latter's collapse became a national tragedy for Serbia and the Serbs: they not only suffered defeat in the modern Balkan wars, survived a decade of sanctions and 78-day NATO bombardments, but lost control of the historical and mental attractor of Serbianism-Kosovo and Metohija.

The support of the "Kosovo project" by the collective West seriously harmed Serbians' ideas of their place in Europe, although all Serbs, unlike Russians, are well aware of the role of great powers, including European ones (primarily Austria-Hungary and Italy), in building the Albanian nation and creating "Great Albania," which during World War II became a place and symbol of genocide against the Serbs. History repeated itself in a new tragedy. Starting from the end of the 20th century, the Kosovo issue consolidated not only the identification code of most Serbs (the slogan "Kosovo je Srbija" ("Kosovo is Serbia"), written specifically in Serbian Cyrillic, is an identification mark of the Serbian patriots), but also the attitude towards Greater Europe expressed by Milorad Pavić back in 1973, when the Serbs felt quite comfortable and secure. 
Weak statehood is the result of the destruction of the "segmented state" (Roeder, 2007). Serbia was "dissolved" in Yugoslavianism and by the will of the "last Habsburg in the Balkans," as the Serbs sometimes call Marshal Tito, lost a significant part of its historical territories. Belgrade became strategically vulnerable. A rather narrow window of domestic and foreign politicy opportunities now forces Serbia to follow the example of the majority of post-socialist countries and choose an "empire by invitation" (Lundestad, 1986), which would be ready to carry the burden of a patron and defender-on rather harsh terms.

Unlike other "new democracies," Serbia has not made the final choice of a patron yet. Belgrade is trying to pursue a multi-vector policy, which helps it maintain the stability of the political regime, balancing between the interests of the leading players in world politics (Germany, the EU, China, NATO, Russia, the U.S., and France). However high the costs and however fair the criticism (Gnedina, 2015), a multi-vector policy, if it is really a skillful and sophisticated game, allows "small nations" (Colomer, 2007) to protect their interests and to reduce their foreign policy dependence on major powers to the maximum extent possible. At the same time, some vectors always get priority. For example, for Central Asian countries, it is Russia and China; for the post-Soviet Caucasus, it is Russia, Turkey and the U.S; and for Serbia, it is the EU and Russia.

The European vector is a rational and realistic choice, in the spirit of E. Carr (1964), for several reasons: political, geographic, economic, and cultural. This approach was formalized by the ratification of the Stabilization and Association Agreement by the Serbian parliament on September 9, 2008. On December 22, 2009, the country applied for EU membership. From that moment on Belgrade has been trying hard to comply with constantly emerging new requirements for not only European but also Atlantic integration (EU membership is tightly linked to strategic military issues). It might seem that the choice in favor of a dualistic (EU-NATO) "empire by invitation" has been made. Belgrade has fulfilled almost all terms of membership, including those requiring it to start the process of normalizing relations with the Republic of Kosovo (RK), and since 2015 it has burdened itself with the 
IPAP (Individual Partnership Action Plan), an operational agreement calling for the closest possible cooperation with NATO, but to no avail. It is obvious that in the medium term, Brussels will keep Belgrade at bay, going no further than general rhetoric about a "European future." As was mentioned above, the country's leadership experienced another political and emotional humiliation during the talks on European integration in Davos (Vučić did not even hide his confusion in an interview later). Nonetheless, he reaffirmed the commitment to join the European Union, even though "having no idea of a timeframe" (Euronews, 2020).

However, things are not that simple in the Balkans. Ever fewer Serbs share the position of the ruling circles regarding accession to the EU. Over the last three years, the Belgrade-based sociological agency Faktor Plus has invariably registered an annual decline in the number of those who support European integration. In 2019, the question "Does Serbia also need to join the EU?" was answered positively by a record low number of respondents-35\%, while 38\% were strongly opposed, and 27\% were undecided (Govoruša and Milojković, 2020). The Serbian leadership's eagerness to enter "the zone dominated by Western powers, which form the pillar of the EU" (Mandić, 2020) disagrees with the opinion of a majority of Serbs, which cannot be ignored. Therefore, it is quite reasonable of Belgrade to pursue a multi-vector policy which, while placing a strategic focus on the EU-NATO, helps it retain a potential for cooperation with Moscow and actively develop relations with Beijing.

Russia, even though not contesting the status of an "empire by invitation," is a very important balancing vector for Belgrade. Russia is a historical ally with which strategic partnership has been maintained since 2013. Given growing tensions in the region and soaring security risks (primarily due to the transformation of the Republic of Kosovo into a transit point for foreign militants), Serbia gives increased attention to the joint fight against international terrorism and to the development of military-technical cooperation.

An almost religious cult of Russia and Vladimir Putin personally, which has developed over the past decades, lends a special quality to 
Russian-Serbian relations. For many years, Putin remains the most popular foreign leader in Serbia: he is trusted by $57 \%$ of Serbs, just as many as Vučić himself (Istraživanje, 2019).

Remarkably, 55\% of Serbs believe that the Russian army is stronger than NATO's; only 19\% think the alliance has an advantage (Western Balkans, 2018). An opinion poll conducted among young Serbs-the most cosmopolitan segment of society, not overburdened by historical myths-displayed almost equal interest towards the EU, Russia, and the U.S. $-58 \%, 65 \%$, and 67\%, respectively (Demostat, 2019). It should be acknowledged, though, that these data show people's expectations rather than the real state of affairs. Nevertheless, Russia's presence in Serbia (although not always effective and consistent) creates a certain political context and conditions for political bargaining, as it provides certain arguments for Belgrade in its relations with the EU. On the other hand, Russia's position on the Kosovo issue, which has remained unchanged since February 17, 2008, and compliance with UN Security Council Resolution 1244 not only provide moral support for the entire Serbian society, but actually allows Belgrade to maintain political agency, thus enabling it to pursue a relatively independent foreign policy (despite all pressure).

Yet Russia is not the only and no longer the main "antidote" to the Euro-Atlantic vector. Seven years ago, another serious player emerged in the Balkans-China. For the time being its presence is limited to purely economic interests. However, the economic penetration of Chinese companies and investors into the spheres that are critical for the viability of a modern state (infrastructure, transport, agriculture, telecommunications and financial networks) will inevitably entail political penetration. It is only a matter of time.

A new era in Serbian-Chinese relations began in April 2012, when the first " $16+1$ " summit was held in Warsaw to unite a group of Central and Eastern European countries under Beijing's auspices. In April 2019, another participant, Greece, joined this Chinese initiative. The " $17+1$ " group is part of the Chinese transcontinental economic and geopolitical vision - an updated version of China's "Going Out" strategy aimed at increasing outbound investment and deeply integrating the economy 
into the world economic system, and eventually positioning itself as a leader in that system (Zeneli, 2017).

China began the construction of the Balkan Silk Road with flagship investments in the port of Piraeus, for it considered Greece a gateway to Europe via the Balkans. Another major project is the $350-\mathrm{km}$ high-speed Belgrade-Budapest railway with a budget of $\$ 2.9$ billion (Glinkina et al., 2018, p. 42). In 2016 and 2017, the bulk of Chinese investment under the Belt and Road Initiative and construction projects-about $\$ 1.8$ billion-was directed to Serbia to build highways and modernize the energy sector (Zeneli, 2017).

With this economic leverage, Beijing is addressing strategic challenges. Its involvement in regional projects in the Balkans enables it to gain a firmer foothold in the EU: the intermediary role of the Balkan states that have free trade agreements with the EU makes Chinese exports significantly cheaper. At the same time, Serbia, like other countries in the region, finds Chinese loans very important as there are no attractive European alternatives for financing the region's huge infrastructure needs, even notwithstanding debt dependence risks. As a result, Russia and the EU cannot but find Chinese penetration into the region increasingly worrisome. China is smoothly and consistently challenging Russia as Serbia's main alternative to the West. Therefore, it is obvious that competition between China and Russia for the position of the main non-European player in the Balkans will only increase in the future.

The U.S.'s role in the restless Balkans, especially in the Kosovo controversy, deserves a separate discussion. Washington is playing its own game, often in opposition not so much to Brussels as to Berlin, London, and Paris. Serbia's current politicians, as well as representatives of the opposition, maintain constant contact with the U.S. Embassy and the Department of State. Nevertheless, it would be wrong to say that Belgrade's policies have an American vector. Rather, it uses Washington as an argument to both play on intra-European contradictions and have a counterweight to Moscow.

Faced with the general crisis of the capitalist system and toughening competition for power, territories and resources, the leading players in world politics are pushing the Serbian leadership towards a multi- 
vector policy. On the other hand, the multi-vector approach is a way out (albeit temporary) of the impasse created by internal problems. In this situation the Kosovo issue can be frozen and the consensus on military neutrality preserved. This combined solution may stabilize the political situation in the country, help it gain time and concentrate efforts on the search for new strategic opportunities.

\section{MAIN OBSTRUCTION TO EUROPEAN INTEGRATION}

In August 2014 (after a certain period of disregard for the Balkans), the so-called Berlin process was launched to achieve three main objectives: final resolution of acute political disputes (including the recognition of Kosovo), economic modernization, and acceleration of democratic processes (Final Declaration, 2014). The Global Strategy-2016 once again confirmed that EU membership was possible on the condition of compliance with membership terms (Shared Vision, 2016). Yet despite the efforts on both sides the Berlin process got deadlocked not only over political disputes, but also over intricate social, economic and institutional problems. In early 2018, an attempt was made to invigorate the process by adopting a document entitled "Credible Enlargement Perspective for and Enhanced EU Engagement with the Western Balkans," which optimistically mentioned 2025 as a possible year of Serbia's and Montenegro's accession to the EU. However, towards the end of 2018 it became obvious that these deadlines were unrealistic and not only for internal Balkan reasons.

At present, as the negotiations in Davos have confirmed, neither Brussels nor Serbian society are enthusiastic about Serbia's EU membership. As was noted above, a national opinion poll conducted in 2019 put the number of people supporting this idea at 35\%. In addition, the journey to Europe may be complicated by new EU terms, such as the demand to recognize "genocide" in Srebrenica (a number of EU countries and Switzerland have already adopted a law imposing criminal punishment for its denial). NATO membership may become a no less stringent condition. However, these are future possibilities. At present, the fate of the Serbian province of Kosovo and Metohija (KaM) remains the main obstacle to European integration. 
The Kosovo issue is the most sensitive for Serbia not only in terms of the "Berlin triad" and relations with NATO, but also in the context of strategic partnership with Russia, which would like to see "Belgrade and Pristina achieve viable and mutually acceptable Kosovo settlement on the basis of UN Security Council Resolution 1244" (Press Conference, 2019). While Moscow is not interested in speeding up the recognition of the Republic of Kosovo, the EU, the U.S., and Middle Eastern countries stand for its "resolution" in the interests of the Albanians. In other words, the recognition of another Albanian polity is a prerequisite for European integration, despite the fact that a vast majority of Serbs are not ready to accept EU membership in exchange for this. Moreover, Brussels' and Belgrade's tactic of "soft" and gradual recognition of the Republic of Kosovo has a double effect.

On the one hand, it adversely affects Serbia's national mentality by breeding apathy and defeatism in people. On the other hand, it creates favorable conditions for revisionist and chauvinistic sentiments. Such a dichotomy can have unpredictable consequences, especially in light of the forthcoming parliamentary elections in Serbia, scheduled for April 26, 2020. The situation is further aggravated by a split in Serbian society over the law on religious freedom, adopted by the Government of Montenegro on December 28, 2019. Although formally an external event, it is perceived by the Serbian majority and the Serbian Orthodox Church as a blow to the unity of the Serbs, wherever they may be living at the moment. It cannot be ruled out that the nationalist sentiment will surge up in Serbia, too.

Another exacerbation of the Kosovo issue was triggered by the socalled "demarcation project." The idea, first expressed by Ivica Dačić, Foreign Minister of Serbia, a few years ago in an interview with the Albanian-language newspaper Zëri, that the Serbs should be left in Serbia, "while the other part, where the Albanians live, should be separated" (Dačić, 2011) has turned into a territorial "swap project." The "demarcation" issue entered the contemporary political discourse in 2018. In part, it is associated with Serbian politician Oliver Ivanović, killed in Kosovska Mitrovica on January 16, 2018. Ivanović was an advocate of the so-called "Cypriot model" for resolving the Kosovo issue. 
The gist of the idea of "demarcation" is as follows: Belgrade would recognize the independence of the Republic of Kosovo in exchange for taking control of Kosovska Mitrovica and the four communities in the north of the region, with the Serbian population in the south being allowed to form their own municipalities. In turn, Pristina would receive villages in the Preševo Valley (southern Serbia), which has a predominantly Albanian population. The fate of Lake Gazivode (a vital water and energy resource) and the Trepča mining complex would be discussed separately, if the demarcation process proves successful. Belgrade and Pristina worked out two options and even made two corresponding maps on the basis of the agreement on the change of the borders reached by Kosovo Prime Minister Hashim Thaçi and Serbian President Aleksandar Vučić in August 2018.

However, the possibility of transferring part of Serbian territories to Pristina caused serious concerns in Serbia, resulting in months of protests and demands for the resignation of Vučić and early parliamentary elections, and a political split in Kosovo (Thaçi vs Haradinaj). Also, it exacerbated contradictions within the EU: Angela Merkel strongly opposed the "swap," whereas Austria supported it. Sebastian Kurtz's position ("If Serbia and Kosovo agree to change borders, Austria will certainly not obstruct this" (Pudovkin, 2018)) became a logical continuation of the Austro-Hungarian policy of building the Albanian nation "as a barrier against the Great Serbia movement” (Toleva, 2018, p. 500-501).

Nevertheless, it was not the opinion of the EU or Central European states that removed the possibility of "demarcation" from the agenda. The authorities in Pristina and Tirana have chosen a new tactic and outplayed Brussels so far. Apparently, this happened not without consultations with Washington: it is not accidental that Ramush Haradinaj, current Prime Minister of Kosovo, is certain that "the United States, regardless of the circumstances, will always stand by Pristina, even if the latter violates all basics of international law" (Borisov, 2018). Obviously, the White House's pro-Kosovo stance is another confirmation that Belgrade is unlikely to rely on Washington in its multi-vector policy. 
As for the new version of "Plan A," Albania's Prime Minister Edvin Rama understands it as "a common strategy for uniting Albanians by 2025" (Vučić, 2018.). Thaçi couples this idea with an inconspicuous threat: "If the EU does not want to accept two Albanian countries with two flags, then it should accept only one" (Thaçi, 2019). The growing ambitions of Kosovo's Albanians have postponed indefinitely the possibility of signing a "legally binding agreement" between Belgrade and Pristina. Such an unconstructive approach predetermined the failure of the April 2019 meeting in Berlin and the refusal to continue the discussion in Paris. In fact, Thaçi's behavior is evidence of the contempt for the EU and preparations for inviting the U.S. to broker the negotiations. It is quite possible that Washington is discussing a new "Dayton deal" with Serbia as well.

Contradictions between Serbs and Kosovar Albanians are not the sole factor that hinders European integration. The problem is the Republic of Kosovo, which is a trouble spot not only for the Balkan region. Albanians' irredentist activity produces destabilization through the use of the universal technology of "geopolitical acupuncture" (Tsymbursky, 2008).

In the case of the Balkans, "geopolitical acupuncture" is the activity of accomplices of international terrorism (Wahhabis, militants of the Kosovo Liberation Army, and ISIS). The U.S. Department of State has quoted 2017 statistics as indicating that the highest percentage of militants fighting for ISIS per capita comes from Kosovo. The Balkan contingent of international terrorism has one very specific featuremilitants go to trouble spots with their wives and children. As many as $10-15 \%$ of jihadists are women, and among them almost $40 \%$ are from Kosovo (Country Reports, 2017).

The EU and the U.S. gave Pristina a free hand unheard of in the Balkans. As a result, the centuries-old balance of peoples inhabiting the region was upset. Russian historian Mikhail Gefter defined this state of affairs, using Alexander Herzen's term, as the "vastness of absence," which allows the search for "a space for expansion" (Pavlovsky, 2015, p. 10). Remarkably, the "space for expansion" for the Albanian segment today is not only the southern part of the Balkans (which is already taken for granted), but the whole of Europe. 
Not only experts but also politicians are concerned about the threat emanating from the region. In November 2019, two countries-Ghana and Nauru-found their own decisions to recognize the independence of the Republic of Kosovo too hasty and violating the provisions of the Helsinki Agreement and UNSC Resolution 1244. The number of countries that have revoked their recognition has grown to 17. It looks like this is just the beginning of the repulsa consulatus process. However complex the process of revoking the recognition by the EU member states may be, Czech President Miloš Zeman's remark that "war criminals should not rule any state in Europe" (Borisov, 2019) confirms the emerging tendency to distance themselves from this toxic entity. At the same time, it should be noted that African, Latin American, and Oceanic countries' cancelations of their previous decisions regarding the Republic of Kosovo were the result of Belgrade's diplomacy. So far, it has been less effective than the campaign for the recognition of Kosovo organized by Pristina with Washington's support between 2008 and 2013. It is important for Belgrade to reduce to 96 the number of countries that recognize Pristina so that the Albanian entity could not join any international organization.

Amid the ongoing diplomatic war over the recognition of Kosovo's independence and the growing terrorist threat from the region, attempts to pressure Serbia into recognizing the Republic of Kosovo look counterproductive not only for the letter and spirit of European integration. This pressure is another argument for rejecting the patronage of the dualistic (EU-NATO) "empire" and opting for a multi-vector policy. At this point, a status quo scenario looks most appropriate as it makes it possible to maintain stability in the region until a solution is devised that will be fair to the Serbs and provide a solid enough argument in favor of the country's military neutrality.

\section{STRATEGIC PARTNERSHIP OF RUSSIA AND SERBIA: OPPORTUNITIES AND CONSTRAINTS}

Relations between Russia and Serbia are a whole world in its own right. By virtue of cultural, historical, socio-economic and political bond, the relations between Russia and Serbia have always developed on the basis 
of broad understanding and have been exceptionally warm, which does not mean, though, that there were no cooling-off periods and even hostility. The latter occurred at a time when fundamentally new social and political systems were taking shape, when Serbia was the backbone of royal and then socialist Yugoslavia, and Russia, the driving force of the Soviet project.

From the very moment of Yugoslavia's breakup, Russia's position has been that of Serbophilia, although retroactively many decisions look too hasty and strategically ill-conceived. Such was, for example, the recognition of the independence of Bosnia and Herzegovinadespite the obvious inevitability of a bloody interethnic war. The Russian leadership signed the relevant documents on April 27, 1992, when sporadic conflicts had already taken place. The real war began a few days later, in May. The analysis of the transcripts of conversations between Bill Clinton and Boris Yeltsin dated April 1996 to December 1999 provides sufficient proof that the March 1999 events could have taken a different course and the Kosovo issue could have been settled then and there. (Yeltsin, 2018, p. 432- 436). The realization of this, of course, is unpleasant. Nevertheless, Russia of the 1990s is associated in Serbia's public mind not with the shameful decisions of the Yeltsin regime, but with volunteers who fought in Bosnia; with the paratroopers' march to Slatina; and with the Russian public's support for Serbian resistance. Today's Russia, which upholds the principles of UNSC Resolution 1244, is perceived by the Serbs as the main defender of their country's territorial integrity. And as was noted above, Russia's principal stand allows Serbia to retain its autonomy in world politics.

Since 2013, Russian-Serbian relations have acquired a different quality. The Declaration on Strategic Partnership has not only opened up new opportunities, but also provided a certain framework for relations between the two countries. Specifically, partnership implies identical assessment of the transformations taking place in the world; commitment to building a "fairer and more democratic order based on collective principles and the rule of law in accordance with the purposes and principles of the UN Charter" (Deklaratsiya, 2013), which is in stark contrast to EU and U.S. policies on a number of 
issues. However, it should be recognized that the strategic partnership en Russe, unlike agreements with the EU and NATO, does not place Belgrade in an institutionally subordinate position. Moscow does not make the development of cooperation conditioned on the final resolution of acute political and territorial disputes (Russia dos not recognize the Republic of Kosovo), modernization of the economy, the adoption of certain standards in the army, or the acceleration of democratic processes. This approach has tremendous advantages as it opens up new horizons. At the same time, it leaves no chance for Russia to position itself as a patron or even articulate its strategic and tactical interests more or less firmly in exchange for certain preferences.

Montenegro's accession to NATO (June 2017) showed once again that partnership in the era of globalization requires not so much an impressive historical background as a robust economic and military-technical foundation. Therefore, central to Russian-Serbian partnership are politics, trade, and the economic and military-technical cooperation, which in the context of the increasing confrontational potential in the region is of paramount importance. During Vlamimir Putin's visit to Serbia on January 17, 2019, twenty-five agreements were signed in all most important spheres of modern development. It might seem that everything is just wonderful, but the significant time lag (five and a half years) that lies between these agreements and the Declaration on Strategic Partnership is surprising. The effectiveness of cooperation today directly depends on timing and precise tactical moves to implement the intentions.

Military-technical cooperation is a special area of strategic partnership, which draws the EU's and NATO's heightened attention. Indeed, Russia is the largest military-technical donor of the Serbian army. The Armed Forces of Serbia have obtained free of charge six MiG-29s, 30 BRDM-2MS armored reconnaissance and patrol vehicles, and 30 T-72MS tanks. Also, Serbia enjoys significant discounts on Russian weapons and military equipment, and other benefits. Belgrade sees the modernization of its army as "a guarantee of peace in the Balkans, especially now that the Republic of Kosovo is creating its own paramilitary units" (Vulin, 2019). 
Serbia's policy of military neutrality is a no less significant guarantee of peace in the region, although there are no provisions to this effect either in the Constitution or in the Defense Strategy. The only institutional confirmation of "military neutrality regarding the existing military alliances until a possible referendum is held that would make a final decision on this issue" is contained in the December 26, 2007 resolution of the Serbian parliament (Rezolucija, 2007). Although no referendum has been held yet, the declared status remains effective and the country's multi-vector policy acquires a military dimension-the intention to develop cooperation with both Russia and NATO's structures.

In modern conditions successful development of strategic partnership will be possible if a smart combination of conventional and non-conventional/innovative approaches is employed. Using traditional images and historical symbols, it is necessary to intensify cooperation between youth organizations, universities and the academic communities. Demand for education in Russia has always been high in Serbia. High tuition costs and the lack of grantbased programs in Western and Chinese universities are the main impediments for Serbian students, whereas in Russia scholarships are granted to Serbian students at the top executive level. For the 20192020 academic year, 120 scholarships have been granted, while in 2016 there were only 85 . How many quotas there will be in 2021 and beyond will depend on the political situation. To win the increasing competition for Serbian students, that is, for the future of Serbia, Russia should develop a comprehensive program of interaction not only between major universities in Moscow (agreements signed by Moscow State University and MGIMO with Belgrade University), but first and foremost between regional higher educational institutions.

Education is an important tool for a long-term "smart power" strategy. To achieve the maximum effectiveness of partnership with Serbia, Russia must complement it with technologies that could produce results in the short term. This concerns, above all, the traditional and new media. Russia's Serbian-language media can be found only on the Internet. Two resources have the maximum audience: Russia Beyond Srbija (RBS, in existence since 2012, owned by TV Novosti and RT) 
and Sputnik Srbija (launched in 2015 and operated by Russia Today). While RBS focuses on non-political news from Russia, Sputnik works as a news agency, with a focus on Russia's official foreign policy agenda and Serbia's domestic policy. The content these sources provide is used by the leading electronic media in Serbia on a daily basis (the audience of the Serbian segment of the Internet is 2.4 million visitors and the leading Serbian website blic.rs has about 2 million visits per month). There are no other Russian or mixed Russian-Serbian media in the country, while many of the top media outlets are controlled by Western companies (N1, Nova TV, Blic, etc.). The "alignment of forces" in the Serbian media market can change with the opening of Russian streaming television (identical in format to Serbian-language RT).

Despite the relatively small economic resources in contrast to those of the EU or China (Russia accounts for $4 \%$ of the trade turnover (International Trade, 2018)), Russia retains certain potential for influence. Russia's initiatives are invariably in high demand. The main constraint on the development of strategic partnership with Serbia is the lack of a long-term comprehensive and clear action program on the Russian side. Many initiatives crop up ad hoc and lack an appropriate socio-economic and political infrastructure. To change the existing imbalance between proposals and expectations, preserve the Russophilic political climate in Serbia and help it maintain its cultural and historical identity (especially amid rapid Uniatization of the Orthodox Church of Montenegro), an intergovernmental commission should be set up and a special mechanism devised to coordinate the activities of public institutions.

By virtue of its central place in this key geo-strategic region, Serbia today-as it has always been in its history-is trying to maneuver and play on the contradictions of the leading actors. The analysis has revealed three overlapping and competing development vectors in modern Serbia.

The first vector is the Euro-Atlantic integration, which, despite its obvious crisis, remains a priority for Belgrade. The choice of the EU 
as an "empire by invitation," requiring the recognition of Kosovo and accession to NATO, illustrates the historical dichotomy: "the choice of a civilizational course of development and the attitude of the Balkans to Europe and Europe's attitude to the Balkans constitute a fundamental contradiction in the region's life and the reason for the dangerous twists and turns in its history and modernity" (Vishnyakov and Ponomareva, 2018, p. 119). The intricate "love-and-hate" relationship between Europe and the Balkans, metaphorically described by Milorad Pavić, in modern conditions is the driving force of Serbian multi-vector political development. Serbia's "love" for Europe runs into so many conditions and restrictions that it gradually turns into "hatred." Political realism forces it to look for new patrons.

The second vector is Russia. It is determined not so much by economic as by cultural, historical, and political factors. It is Russia that over the last twenty years has served as a power that ensured Serbia's political agency and helped it maintain its status in world politics. The significance of Serbia lies in its military neutrality and its unwillingness to recognize the independence of the Republic of Kosovo, and these are precisely the issues on which Belgrade enjoys Moscow's full support. However, this influence needs to be stepped up, and this requires the most serious efforts and proposals to shape a new agenda.

The third vector is China. While traditional players in the Balkans appeal to history and try to play on the phobias of the Balkan peoples, China has been expanding its presence in the region exclusively by economic means. Beijing is attractive for Serbia not only financially, but also in terms of political neutrality: Chinese companies are ready to work with both "-philes" and "-phobes," regardless of which part of the globe they come from. Moreover, the average Serb has positive expectations with regard to China: preservation of jobs and creation of new ones, infrastructure development, cheap goods, social mobility, etc. On the other hand, China sets foot on Balkan soil to create a basis for its further expansion into Europe. Perhaps it is not the EU, but China that is destined to become the integrator of multi-speed Europe.

In view of the above, in the medium term, a multi-vector policy seems to be the only opportunity for Serbia to break the deadlock 
of strategic vulnerability, preserve its historical and cultural identity, strengthen the status of a regional player and protect its political agency on the international stage. Edward Carr and Hans Morgenthau are right: the security dilemma can be resolved only by ensuring a balance of power and interests.

\section{References}

Borisov, A., 2018. Kosovo poluchilo svoyu armiyu [Kosovo Got Its Army]. Rossiikaya gazeta, 14 December [online]. Available at: <https://rg.ru/2018/12/14/ kosovo-poluchilo-svoiu-armiiu.html $>$ [Accessed 18 November 2019].

Borisov, A., 2019. "Proekt Kosovo" utrachivaet podderzhku v mire ["The Kosovo Project" Is Losing Support in the World]. Rossijskaya gazeta, 8 September [online]. Available at: <https://rg.ru/2019/09/08/proekt-kosovo-utrachivaetpodderzhku-v-mire.html> [Accessed 19 November 2019].

Briefing, 2019. Briefing Macron's View of the World. The Economist, 9 November, pp. 17-20.

Carr, E., 1964. The Twenty Years' Crisis, 1919-1939: An Introduction to the Study of International Relations. New York: Harper\&Row.

Colomer, J.M., 2007. Great Empires, Small Nations: The Uncertain Future of the Sovereign State. London-New York: Routledge.

Conley, H.A., Hillman, J.E. and Melimo M., 2019. The Western Balkans with Chinese Characteristics. Center for Strategic \& International Studies (CSIS), July 30 [online]. Available at: <https://www.csis.org/analysis/western-balkanschinese-characteristics $>$ [Accessed 17 November 2019].

Country Reports, 2017. Country Reports on Terrorism. [online]. Available at: $<$ https://www.state.gov/reports/country-reports-on-terrorism-2017/> [Accessed 18 November 2019].

Dačić, 2011. Dačić nije tražio podelu Kosova! [Dachic Did Not Ask for the Division of Kosovo!]. Istinomer, 11 October [online]. Available at: <https:// www.istinomer.rs/ocena/1375/Dacic-nije-trazio-podelu-Kosova> [Accessed 18 November 2019].

Deklaratsiya, 2013. Deklaratsiya o strategicheskom partnyorstve mezhdu Rossī̄skoī Federatsieī i Respublikoī Serbiya [Declaration on Strategic Partnership between the Russian Federation and the Republic of Serbia]. [online]. Available at: <http://www.kremlin.ru/supplement/1461> [Accessed 16 November 2019]. 
Demostat, 2019. Demostat. [online]. Available at: $<$ http://demostat.rs/sr/vesti/ istrazivanja/mladi-i-politika/718> [Accessed 16 November 2019].

Yeltsin, 2018. Declassified Documents Concerning Russian President Boris Yeltsin. [online]. < Available at: https://clinton.presidentiallibraries.us/items/ show/57569> [Accessed 18 November 2019].

Euronews, 2020. Euronews, 23 January [online]. Available at: <https://www. euronews.com/2020/01/23/serbia-committed-to-joining-european-union-sayspresident-aleksandar-vucic> [Accessed 29 Jan. 2020].

Fenenko, A, 2019. Neorealism v politicheskoī teorii [Neorealism in Political Theory]. In: Gaman-Golutvina, O. and Nikitin, A. (eds.) Sovremennaya politicheskaya nauka: metodologiya [Contemporary Political Science: Methodology]. Moscow: Aspekt Press, pp. 61-83.

Final Declaration, 2014. Final Declaration by the Chair of the Conference on the Western Balkans. Berlin. 28 August [online]. Available at: <https://www. auswaertiges-amt.de/blob/264688/953e9f4b2f0b008d20bf6a65bfb4ebbe/140828abschlusserkl-konf-westl-balkan-data.pdf> [Accessed 16 November 2019].

Glinkina, S., Kulikova, N., Turaeva, M., Golubkin, A., and Yakovlev, A., 2018. Kitaīskī faktor $v$ razvitii stran rossīskogo poyasa sosedstva: uroki dlya Rossii [The Chinese Factor in the Development of the Russian Neighborhood Belt: Lessons for Russia]. Moscow: Institute of Economics RAS.

Gnedina, E., 2015. 'Multi-Vector' Foreign Policies in Europe: Balancing, Bandwagoning or Bargaining? Europe-Asia Studies, 65(7), pp. 1007-1029. DOI: $10.1080 / 09668136.2015 .1066313$.

Govoruša, N. and Milojković, M., 2020. "BLIC” ISTRAŽUJE Zašto su se Srbi "ohladili" od EU ["BLIC" RESEARCH. Why Serbs "Cooled Off" the EU]. Blic, 20 January [online]. Available at: <https://www.blic.rs/vesti/politika/ pridruzivanje-srbije-eu/d1dlzm8> [Accessed 29 January 2020].

International Trade, 2018. International Trade Centre [online]. Available at: $<$ http://www.intracen.org/layouts/CountryTemplate.aspx?pageid=4724464503 4\&id=47244652579> [Accessed 20 November 2019].

Istraživanje, 2019. Istraživanje: Vučić ubedljivo najpopularniji političar [Survey: Vučić Is Convincingly the Most Popular Politician]. Vecherne novost, 3. January [online]. Available at: <http://www.novosti.rs/vesti/naslovna/ politika/aktuelno.289.html:769462-Istrazivanje-Vucic-ubedljivo-najpopularnijipoliticar-Putinu-najvise-poverenja-medju-svetskim-liderima> [Accessed 17 November 2019]. 
Jamieson, F. and Kumar, I., 2020. Serbian President Vučić 'fed up of being lectured' over ties with Russia and China. Euronews, 21 January [online]. Available at: <https://www.euronews.com/2020/01/21/serbia-president-vucicfed-up-of-being-lectured-over-ties-with-russia-and-china> [Accessed 29 January 2020].

Lundestad, G., 1986. Empire by Invitation? The United States and Western Europe, 1945-1952. Journal of Peace Research, 23(1), pp. 263-277.

Mandić, M., 2020. Ruski pragmatizam i srpsko slepilo [Russian Pragmatism and Serbian Blindness]. Demostat [online], 29 January. Available at: <http:// demostat.rs/sr/vesti/analize/ruski-pragmatizam-i-srpsko-slepilo/809> [Accessed 29 January 2020].

McKeogh, C, 2016. The Political Realism of Reinhold Niebuhr: A Pragmatic Approach to Just War. Heidelberg: Springer.

Morgenthau, H., 1973. Politics Among Nations. The Struggle for Power and Peace. 5th ed. New York: Alfred A. Kropf.

Pavić, M., 2003. Lovtsy snov [Dream Hunters]. Saint-Petersburg: AzbukaKlassika.

Pavlovsky, G., 2015. Sistema RF. Istochniki rossīiskogo strategicheskogo povedeniya: metod G.F. Kenana [The System of the Russian Federation. Sources of Russian Strategic Behavior: G. F. Kenan's Method]. Moscow: Evropa.

Press Conference, 2019. Press-konferentsiya V. Putina i A. Vuīchicha. [Press conference of V. Putin and A. Vučić] [online], 17 January. Available at: <http:// www.kremlin.ru/events/president/news/59693> [Accessed 18 November 2019].

Pudovkin, E., 2018. Gibkaya granitsa [A Flexible Border]. RBC [online]. Available at: <https://www.rbc.ru/politics/29/08/2018/5b86769b9a794786677 1c72f $>$ [Accessed 18 November 2019].

Rezolucija, 2007. Rezolucija Narodne skupshtine o zashtiti suvereniteta, teritorijalnog integriteta i ustavnog poretka Republike Srbije [Resolution of the National Assembly on the Protection of Sovereignty, Territorial Integrity and Constitutional Order of the Republic of Serbia]. [online]. Available at: $<$ https://www.srbija.gov.rs/kosovo-metohija/index.php?id=80729> [Accessed 16 November 2019].

Roeder, P.G., 2007. Where Nation-States Come From: Institutional Change in the Age of Nationalism. Princeton: Princeton University Press. 
Shared Vision, 2016. Shared Vision, Common Action: A Stronger Europe. A Global Strategy for European Union's Foreign and Security Policy. European Union External Action [online]. Available at: https://eeas.europa.eu/sites/eeas/ files/eugs_review_web.pdf [Accessed 16 November 2019].

Thači , H, 2019. Thači preti EU formiranjem "Velike Albanije" [Thai Scares the EU by Forming "Greater Albania"]. Telegraf, 31 May [online]. Available at: $<$ https://www.telegraf.rs/vesti/politika/3066812-tacija-preti-eu-formiranjemvelike-albanije-ako-ne-zele-da-prihvati-dve-albanske-drzave-sa-dve-zastaveneka-prihvate-samo-jednu-zastavu> [Accessed 16 November 2019].

Toleva, T., 2018. Avstro-Vengriya i stanovlenie albanskoī natsii [Austria-Hungary and the Formation of the Albanian Nation]. Moscow: Institute of Slav Studies.

Tsymbursky, V., 2008. Neft' i geoterror [Oil and Geoterror]. Intelros [online]. Available at: <http://www.intelros.org/lib/recenzii/cimburskyl.htm\#22> [Accessed 16 November 2019].

Vishnyakov, Y. and Ponomareva, E., 2018. Serbiya na Balkanah: izobretenie "porokhovogo pogreba Evropy" [Serbia in the Balkans: The Invention of "Europe's Powder Magazine”]. Sovremennaya Evropa, 7, pp. 108-121. DOI: http://dx.doi.org/10.15211/soveurope72018115129.

Vučić, M., 2018. Shta su Haradinaj i Rama (do)govorili u Pechi? [What did Haradinaj and Rama negotiate in Pechi?]. Raskrikavanje, 28 November [online]. Available at: <https://www.raskrikavanje.rs/page.php?id=320> [Accessed 16 November 2019].

Vulin, 2019. Ministar Vulin: Nashe naoruzhavaње u funkciji mira [The Minister Vulin: Our arming for peace.] MoD of the Republic of Serbia, 30 July [online]. Available at: <http://www.mod.gov.rs/cir/14226/ministar-vulin-nasenaoruzavanje-u-funkciji-mira-14226> [Accessed 17 November 2019].

Waltz, K.N., 1979. Theory of International Politics. New York: McGraw Hill.

Western Balkans, 2018. Western Balkans: Between East and West. Public Opinion Research in Bosnia and Herzegovina, Macedonia, Montenegro, and Serbia. NDI [online]. Available at: <https://www.ndi.org/sites/default/files/ Download\%20Report_0.pdf> [Accessed 16 November 2019].

Zeneli, V., 2017. What Has China Accomplished in Central and Eastern Europe? The Diplomat, 25 November [online]. Available at: <https:// thediplomat. com/2017/11/what-has-china-accomplished-incentral-and-eastern-europe/> [Accessed 16 November 2019]. 